Article

\title{
Beyond Time and Space-The Aspiring Jurassic Geopark of Figueira da Foz
}

\author{
Paulo Trincão ${ }^{1,2,3, *}$, Estefânia Lopes ${ }^{4}$, Jorge de Carvalho ${ }^{1,3}$, Sebastião Ataíde ${ }^{1}$ and \\ Margarida Perrolas 1 \\ 1 City Council of Figueira da Foz, 3084-501 Figueira da Foz, Portugal; j.rbcarvalho13@gmail.com (J.d.C.); \\ joao.sebastiao.ataide@gmail.com (S.A.); margarida.perrolas@cm-figfoz.pt (M.P.) \\ 2 Exploratório Centro Ciência Viva de Coimbra, 3040-255 Coimbra, Portugal \\ 3 Geoscience Center, University of Coimbra, 3030-790 Coimbra, Portugal \\ 4 Institute of Earth Sciences-Geology Centre, University of Porto, 4169-007 Porto, Portugal; \\ estefania.lopes@exploratorio.pt \\ * Correspondence: paulo.trincao@exploratorio.pt; Tel.: +351-239-703-897
}

Received: 1 April 2018; Accepted: 15 May 2018; Published: 24 May 2018

\begin{abstract}
Figueira da Foz municipality has a very important geoheritage significance and the local authorities, the population and the academics recognize it. Even though it is a small-scale coast, unique geological and geomorphological features are found. It is well-known due to its international stratigraphic relevance given by the establishment of two stratotypes. The rocks of the region are well exposed along the shore, the archaeological patrimony, the cultural heritage and the biodiversity complete the region with high quality, and provide a global classroom. It is a catalogue of scientific, touristic and educational values that is being used for a long time. Because of all this became officially by UNESCO an Aspiring Jurassic Geopark of Figueira da Foz in 2018.
\end{abstract}

Keywords: Aspiring Geopark; Figueira da Foz; Jurassic; culture; Mezo-Cenozoic; GSSP; ASSP

\section{Introduction}

Figueira da Foz municipality, located at Central Portugal, is a land of mountain (Boa Viagem mountain), sea (Atlantic Ocean), river (Mondego), and beaches. Due to its unique geological and geomorphological features has plenty of geoheritage significance, onshore and offshore. It is a worldwide-known site due to its international stratigraphic relevance given by the establishment of two stratotypes, the Global Boundary Stratotype Section and Point for the base of the Bajocian Stage and the Auxiliary Stratotype Section and Point for the base of the Bathonian Stage. In order to protect it, in 2007 Cabo Mondego was classified as Natural Monument [1], and the ceremony of attribution of a Golden Spike occurred in 2016, which corresponds to a worldwide recognition of the area; There is an abundant paleontological heritage of the region (dinosaurs footprints, gastropods, fossil reefs and plants, exposed and identified in an old coal exploration, etc.). Beyond the Jurassic, there are important quaternary geomorphosites (such as lakes and dunes). The remarkable geodiversity of these geomorphosites justifies the implementation of strategies in order to conserve and promote the geosites though the Aspiring Geopark approach aims to go beyond the geological resources mentioned. The archaeological patrimony (Pre-historic, Fenician, Romans elements and Industrial patrimony), the cultural heritage (monuments, churches, light houses, traditional fishing, salt and rice production) and the biodiversity (mainly located at Ramsar and Natura 2000 sites) complete the region with high quality, and provide a global classroom by which to study the region. It is a catalogue of scientific, touristic and educational values that is already being used for a long period of time.

The Aspiring Jurassic Geopark of Figueira da Foz, with $2845 \mathrm{~km}^{2}$ (Figure 1), is an initiative of the municipality (local power) as a model of territorial sustainable development that incorporates natural 
and anthropic heritage, community cohesion and tourism (as part as the national tourism strategy). It is therefore being built around the interaction between nature and culture and it is envisaged as the place where one could explore the connection between the natural and the anthropic worlds. It is highly interdisciplinary and it has the support from the local authorities, the community and from Earth, Life, and Social Sciences specialists (architects, fine-art artists, anthropologists, archaeologists, historians, museologist, teachers, economists) that emphasize this broader approach.

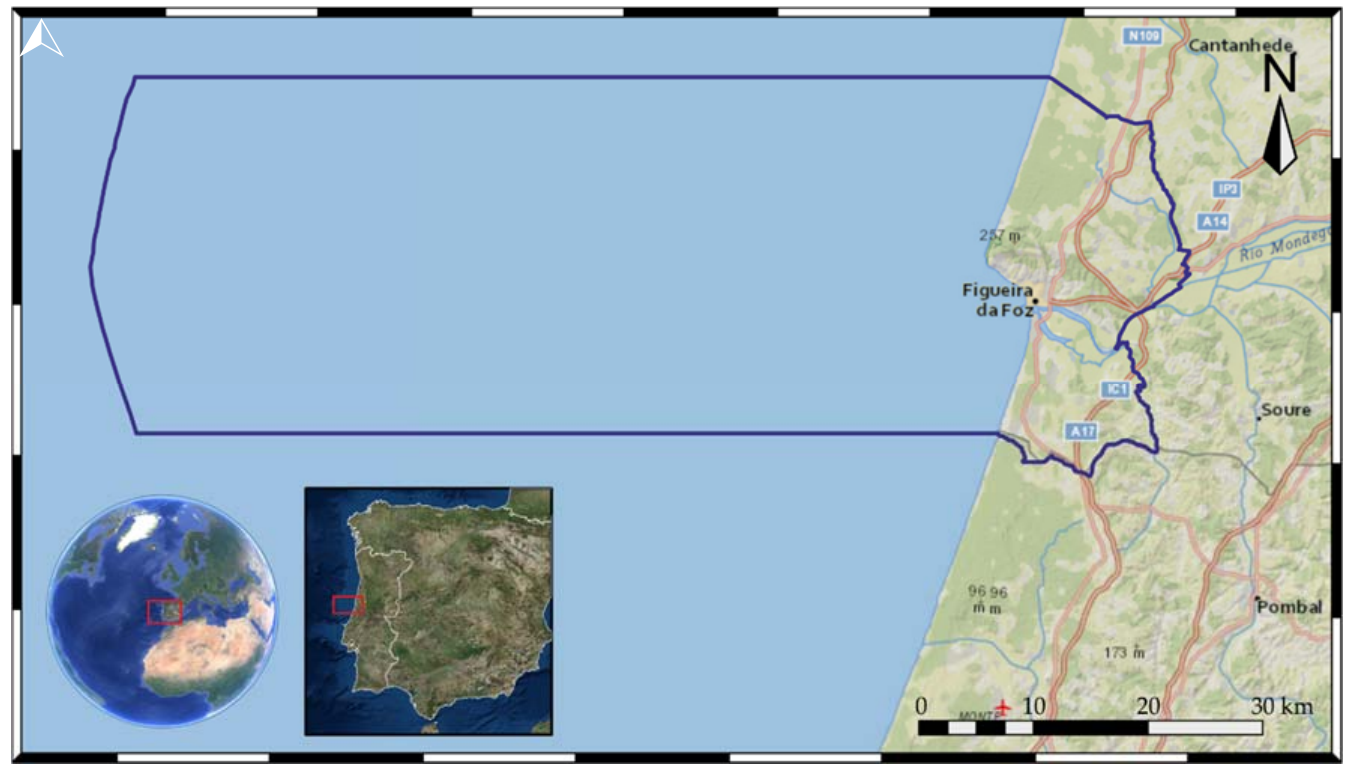

Figure 1. Localization of the Aspiring Jurassic Geopark of Figueira da Foz.

Figueira da Foz Municipality has all the condition to create the first Geopark in the Mezo-Cenozoic border, under the name of "Geoparque Jurássico da Figueira da Foz" and will be a model of development based on the conservation and valorisation of its geological heritage, with the community's imprint and involvement. The recognition by UNESCO and the creation of the Geopark will organize and structure a reality already seen in Figueira da Foz, and the awareness created will enable the team to maximize a feasible planning and ensure a sustainable future of the site.

With this work it is aimed to strengthen and promote the importance of this region and it is intended to present the concept and principles of the Aspiring Jurassic Geopark of Figueira da Foz, the strategy for community evolvement and development, as well as the geological attractions in the area.

\section{Aspiring Geopark in Figueira da Foz: Geological Heritage}

When it comes to Figueira da Foz's territory, geological history represents an evolution period of approximately 180 million years, marked not only by the numerous evolution stages of the Lusitanian Basin through the Mesozoic, but also the geodynamic context of the Cenozoic sediments, that are more recent.

Figueira da Foz displays an inestimable geological value. The fact that it is possible to analyse in detail a large portion of the only existing basin within the North Atlantic margin containing a wide surface exposure, allows the access of certain historical testimonies of Earth's span, that by its preservation and representation of the geological systems' dynamics which generated them, has a patrimonial value at a worldwide scale. These testimonies are essential to attract a considerable number of curious people, as well as teams of professionals and specialists within a whole variety of fields to perform investigations at national and international levels [2]. 
The first geological studies date back to mid-18th century, with the discovery of coal layers from late Jurassic and its exploration for economical purposes [3]. However, it was only after the second half of the 19th century that the first academical studies were established. From this point on, the location of mining works in fossil strata, contributed exceptionally for the development and increase of scientific research, not only within the coal exploitation surrounding area, but also the Mesozoic in Portugal, improving research related to biostratigraphy and general lithologic characteristics $[3,4]$. Hand in hand with the previous research studies, geological cartography research on the Northern zone of the territory [5] and on the Southern zone [6] can be highlighted, which is the source of the geologic map of Figueira da Foz's territory and the base for the Aspiring Geopark geological mapping propose (Figure 2).

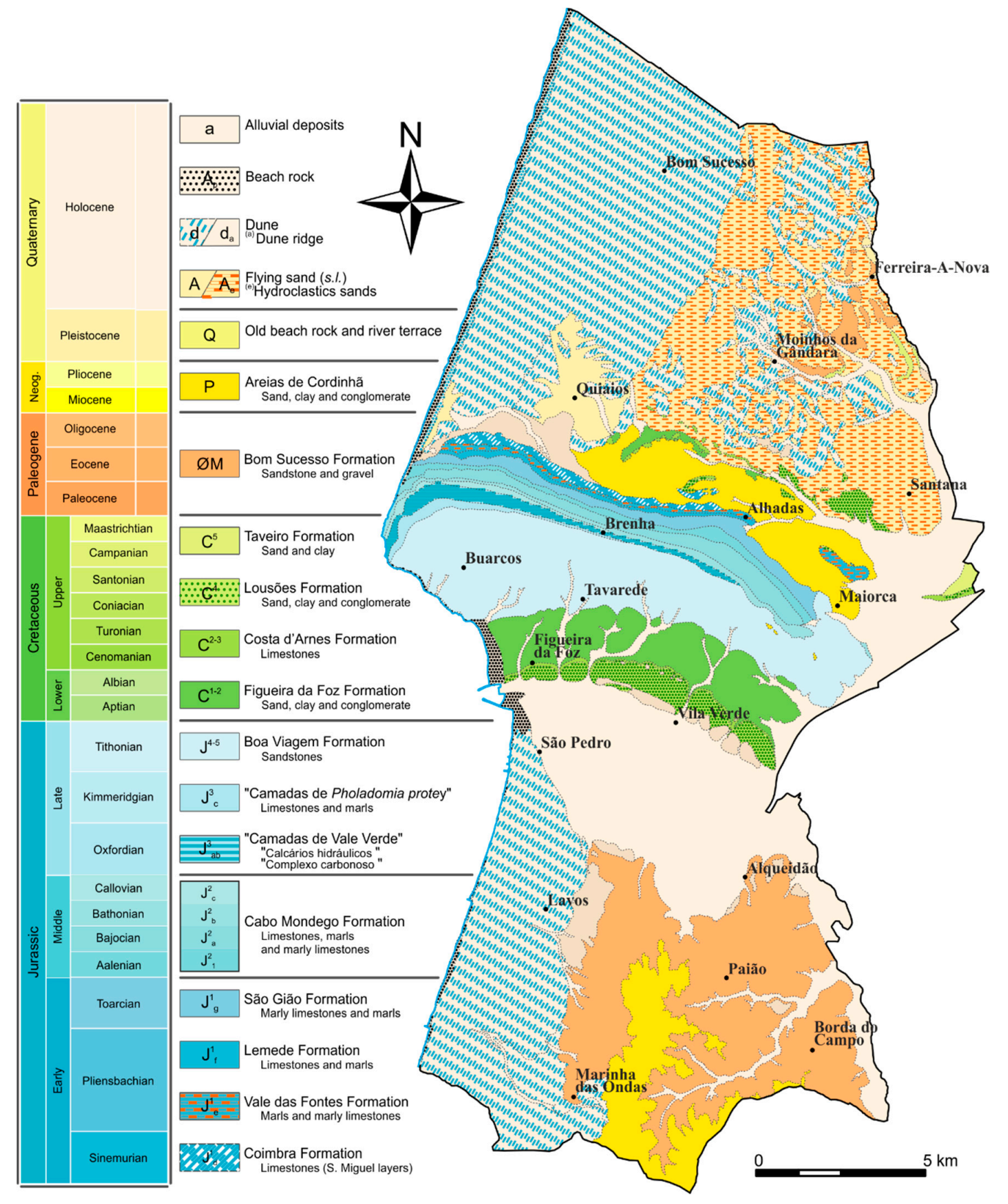

Figure 2. Geological mapping of the Aspiring Geopark. Section Onshore. Based on the Geological mapping 1/50,000, sheets 19-A (Cantanhede) and 19-C (Figueira da Foz) [5,6]. 
The lower Jurassic (Coimbra Formation, Vale do Fontes Formation, Lemede Formation, and S. Gião Formation) [7] corresponds to different depositional megassequences, limited by well-defined regional discontinuities from a biostratigraphic point of view [8,9]. This stratigraphic interval comprises intercalations of marls and marly limestones in decametric layers with sporadic nektonic macrofauna (ammonoids and belemnites). Rocks located on this stratigraphic interval show the regressive tendency of the sedimentary units, interpreted as having once been deposited on a deep-water environment, with a distal ramp established throughout the Toarcian $[9,10]$, corresponding to the SAG interval that follows the late Triassic rifting episode [11].

The middle Jurassic records in Figueira da Foz region correspond to the Cabo Mondego Formation [9]. The eustatic, climatic and topography conditions allowed a calm and monotonous sedimentation typical of external marine environments. The Cabo Mondego Formation is organized in thickening upwards sequences of marl, marly limestone and clay, with ammonites, belemnites, brachiopods and trace fossils [12,13]. Occasionally the sequences are disturbed by some natural episodes of synsedimentary deformation and gravitational resedimentation, which can be evidenced by the presence of calciturbidites and debris flows [14,15]. The continuous record on ammonite assemblages including taxa of Boreal and Mediterranean affinities enabled the establishment of an accurate biostratigraphic framework for the Middle Jurassic. This set of factors translates into a significant increase in their potential for correlation at a global scale [16], allowing to define two points of global interest based on paleontological and stratigraphic standings (Figure 3). The first one, concerns the Global Stratotype Section and Point (GSSP) of the Bajocian Stage, located in a particular section near Murtinheira Beach, becaming an international outcrop reference in 1996 [17,18]. The second one corresponds to the Auxiliary Stratotype Section and Point (ASSP) at the base of the Bathonian at Cabo Mondego (Section 2), $7 \mathrm{~km}$ north of the city of Figueira da Foz [19]. The abundant existence of fossil assemblages in these strata is frequent, highlighting the study of micro and macrofaunas of invertebrates [20-22] and its evolution during Jurassic times, as well as its paleoenvironmental and paleogeographic implications [23-25]. The above mentioned represents a geosite of international relevance [26-30].
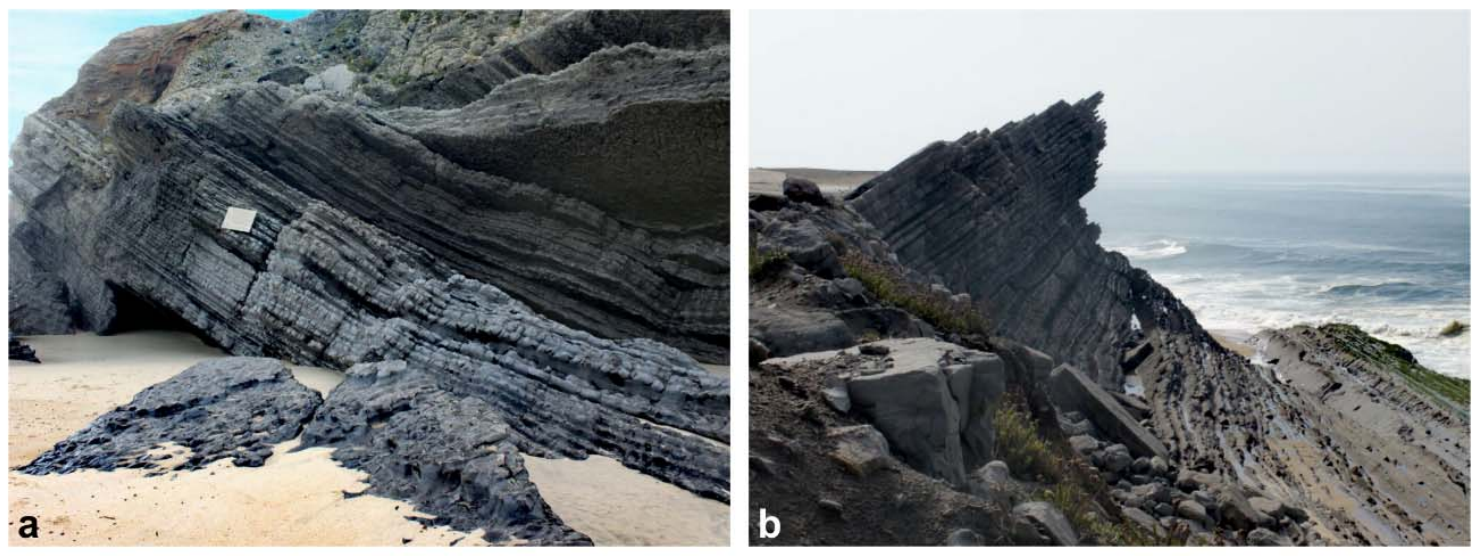

Figure 3. (a) Alternating marls and limestones of the Global Stratotype Section and Point (GSSP) of the Bajocian Stage in the Murtinheira Section; (b) Auxiliary Stratotype Section and Point (ASSP) for the base of the Bathonian Stage, located on Section 2 in Cabo Mondego. By Aspiring Jurassic Geopark of Figueira da Foz.

The upper Jurassic succession consists of outer-ramp deposits sharply overlaid by a carbonate sandbody, that contains an irregular, scalloped and bored surface, which is interpreted as a hardground and erosion surface [31]. The above mentioned expresses a disconformity at a regional level, representing a deposition gap of about $3 \mathrm{Ma}$ from the upper Callovian to the middle Oxfordian [32], which points to a strong tectonic control with an uplift, and not only to a simple eustatic episode [29]. 
This surface is seen as a lowstand surface, overlaid with reddened, laterally variable oyster-coral sandstones, and limestones with further minor subaerial exposure surfaces, represented by shale and bituminous limestones with numerous lignite beds, therefore corresponding to the Complexo Carbonoso formation. On the top of the sequence, the Calcários Hidraulicos formation include limestones, clays with lignites and pyrite. Both formations referred above were later grouped and designated as Camadas de Vale Verde. This sequence corresponds to the original mining exploitation that started in mid-18th century and having a fossil association could be beneficial to develop research in fields like palaeobotany, through the study of plants remains [33-35], and also in the discovery of dinosaur footprints [36,37] or fossil fishes on the lagoonal freshwater limestones [38,39]. From a sedimentary point of view, these deposits are articulated in eight units corresponding to the implantation and development of small delta devices, established in a barrier-island lagoon complex. The environments' temporal evolution was being partly controlled by the delta dynamics itself, contributing for a progressive confinement of the environment [40].

The formation above, "Camadas de Pholadomya protei", consists of biomicritic limestones containing bivalves. This event marked the beginning of marine sedimentation conditions, occurring in open bay environments influenced locally by the entanglement of terrigenous from adjacent coastal zones [41].

It is assumed that the passage between the Upper Oxfordian and the Kimmeridgian-Titonian set coincides with the total replacement of carbonate deposits with a sequence of siliciclastic nature. In Cape Mondego, this set is represented by the Boa Viagem Formation and it is interpreted as a fluviodeltaic sequence in which carbonaceous levels of marine origin are intercalated [41].

At the beginning of the Cretaceous period, some transformations of tectonic origin occurred in the Lusitanian Basin. These transformations resulted in the upwelling of the entire northern sector and consequent emersion and exposure of the oldest Jurassic series [42]. Following the late Aptian tectonic event, Figueira da Foz Formation corresponds to the fast progradation of braided fluvial systems that cover the Jurassic successions, and include several members defined the distribution of clastic facies and marine intercalations [43]. This continental characteristic allows the conservation of plant macrofossils [33] or microfossil remains [44,45] in the Early Cretaceous of Figueira da Foz.

Within the long-term eustatic rise, the maximal Cretaceous transgression in the basin was during the initial Upper Cenomanian [46,47]. At Figueira da Foz region, this transgression culminated/ended with the installation of a shallow carbonate platform over a system of alluvial and littoral plains with coarse siliciclastic sedimentation [48]. The introduction of fully marine environments allowed the expansion of the carbonate platform and the widespread of the ammonites fauna, as well as a rich and highly diverse benthic fauna of invertebrates [47].

Outcrops corresponding to Cenozoic deposits resulting from a relationship between eustatic variation and geomorphological characteristics inherited from the terrain [49]. A new transgressive maximum developed an extensive sandy coastline fuelled by several delta systems fed by the hydrographic systems precursors of the main current watercourses [50]. Another consequence of this eustatic increase can be verified by the development of a generalized abrasion platform and the appearance of the "Raised Beaches" and the "Lighthouse Deposits" [51]. Surfaces that underwent changes due to some post-Pliocene tectonic activity, expressed by a regional uplift [50] and perhaps by the recent tectonic rejoin associated with the Quiaios Fault.

During the Holocenic, the geodynamic and mechanical processes, that act in all the previously formed structure are emphasized. We highlight the karstification processes, evidenced by the presence of a set of dolines in the Serra da Boa Viagem [52]. The dune fields north of the Serra da Boa Viagem and the different dynamics and stages of their formation [53-55]. The Mondego estuary and the morphological controls that allow the development of the landscape, and the use of the same control by man $[56,57]$. The dune system that crosses, next to the marginal, from North to the South, all the municipality of Figueira da Foz.

The offshore sector geologic mapping, corresponding to the continental margin nearby the Municipality of Figueira da Foz (Figure 4), was developed in the late 20th century. It takes into 
accounts it assortment in systematic marine geology studies based on single-beam echo sounder, side scan sonar data, seismic reflection profiles, boreholes, well logs and bottom samples [58]. It is mainly characterized by formations of Cretaceous and Cenozoic age that lie on top of Variscan Pre-Cambrian and Palaeozoic rocks [59] and it is represented on geological mapping of continental margin at 1:500,000 scale [60].

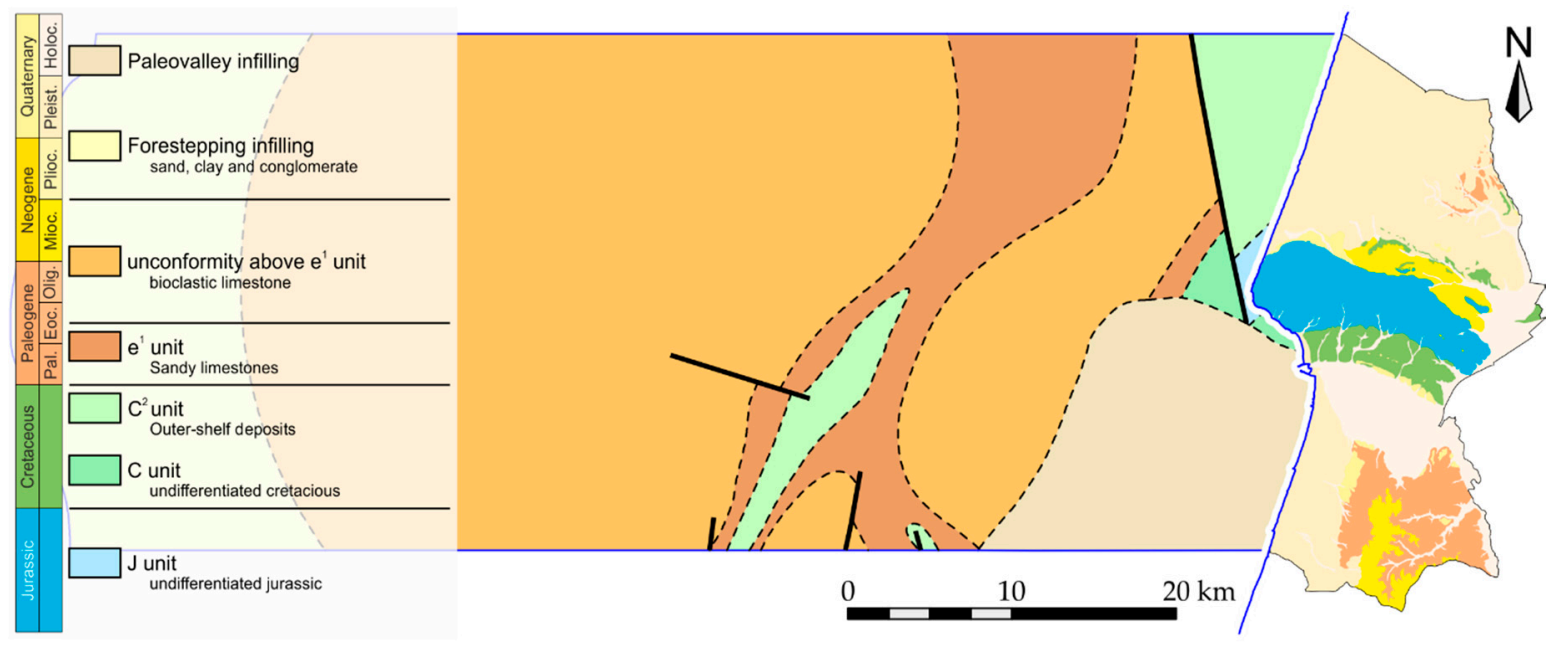

Figure 4. Geological framework of the offshore section on Aspiring Geopark of Figueira da Foz. Based on the Geological mapping 1/500,000 [60].

\section{Aspiring Geopark in Figueira da Foz: Anthropomorphic and Industrial Heritage}

The systematization of the archaeological study is, by its nature, a continuous work, which in this synthesis promotes a general view of human occupation in the territory of Figueira da Foz county. This summary view is based on the decisive contribution of the illustrious archaeologist Santos Rocha, promoter of the archaeological culture of the county, to whom the Municipal Museum attributes its name, and also, the meticulous work of investigation of the archaeologist Ana Margarida Ferreira.

To better understand the occupation of the territory, it is important to inform that in place of the rice fields, which now inhabit the lower Mondego, there existed a navigable delta, the old Mondego, endowed with a geomorphological condition that promoted the human occupation of its banks. Santa Olaia, as we shall see, is an excellent description of permanence over time, where the overlapping of the anthropomorphic layers reminds us of successive occupations that have been forged over the ages. The Phoenicians, who occupied these banks, profited greatly from the navigability of the Mondego, on the other hand, the Romans managed to sail to Coimbra by sea. However, the human occupation of the Munda (The name used by the Romans for the Mondego River, which will still prevail during the Middle Ages), and its alteration over time, cannot be dissociated from the human occupation, the animal husbandry and cultivation of the early Neolithic sedentarizations, the production of Chalcolithic ceramics, the commercialization and transformation of the Phoenician metals of the Iron Age, the construction of roads and villages of the Roman conquest, the stabilization of medieval villages and military forts or, more recently, the production of rice and salting very relevant to the cod industry.

\subsection{Paleolithic to Neolithic-The First Settlements}

The first marks of civilization in the territory date back to the Paleolithic period, about 40,000 BC. In Santa Olaia, Fontela and in the lands bordering the Dolmen of the Carnicosas, we find stone-chipped instruments, characteristic of the Paleolithic collectors. It is argued that these places will have more information yet to be revealed [61] and, therefore, should be excavated, especially in the river terraces of the former Mondego, still visible in the area of Fontela. 
The existence of evidence of the Mesolithic era is one of the most important contemporary archaeological finds [61]. Quinta das Pitanças, previously placed in the chronological space of the Neolithic period [62], took on new contours when the geologist Pedro Callapez pointed to the microlithic collection on the surface. The multidisciplinary work between archaeologists and geologists has made it possible to justify that, in the light of the new findings and considering the geomorphology of the place, we find in this place a mesolithic occupation, located chronologically on the Portuguese coast between 7000 and 5000 BC, which corroborate the human occupation in the old Mondego estuaries.

In the study of the prehistory of Figueira da Foz county, the Neolithic period (5500 to 3000 BC) emerges with great prominence. The sandy soils of the estuary of the old Mondego river were very important for the first attempts at cultivation, animal reproduction and consequent sedentarization, while the calcareous strip of the Serra da Boa Viagem was essential for the first megalithic funeral experiences and, on the other hand, there would have been no Chalcolithic pottery without the sandy deposits made up of Jurassic red shales [63,64].

The limestone massif of the Serra da Boa Viagem will have been the Baixo Mondego region with the greatest demographic expression during Recent Prehistory [61]. The various Neolithic finds, with megalithic and chalcolithic specifications are divided into three major zones. In the northern part of the Serra da Boa Viagem we find the Vale do Lírio and Junqueira [63,65-67], Arruela [68], Vale do Romão [61], which allowed the classification of the great megalithic necropolis of the Serra da Boa Viagem as a National Monument, since 1910. In the Northern slope we find the Arneiro zone, with national and international scientific value [69-71] and also some isolated finds to the East and North of this place. The third occupation spot is located in the south of the county, south of Mondego, in the Paião, Cabaços and Charneca da Cabreira zone. The southern part of the county is the least explored, but it is known by the current pre-historians for its great archaeological potential, an example of which was the excavation done by Santos Rocha, in the Municipality of Soure, in 1897, that allowed the discovery of one of the first known sites of the Portuguese Neolithic [72].

With the use of the digital tool of georeferencing, the archeologist was able to draw an area circumscribed by the altimetry that encompassed all 22 Dolmens, in what is considered one of the main necropolises of the Iberian plateau [68].

“(...) based on shallow excavations, open to the natural soil and constructed with slabs, generally of large dimensions and coming from other places, whose typology rests, in general, on the existence of a polygonal chamber and a gallery, having been closed in mounds of artificial earth, in a conical form." [61]

\subsection{Copper and Bronze Age—A Demographic Downfall}

If on one hand the Neolithic findings were abundant, on the other, the Chalcolithic and Copper finding were almost none. However, decorated ceramics and spearheads were found in pure copper between Tavarede, Santa Olaia and Ferreira Nova, which points to the existence of a medium height settlement with defensive characteristics.

The Bronze Age, between 2250 and 600 BC, appears insignificant when compared to the Neolithic, which raised the question of the demographic impoverishment that this region suffered at the end of the Neolithic period. However, we can also mention the existence of settlements of the Late Atlantic Bronz [73] between Castro de Santa Olaia and the sandy and dune area south of the County [74].

\subsection{Iron Age-Phoenician and Roman Occupation}

The Figueiranse's archeology is known mainly by the Iron Age, agreed between the sec. XI/VIII a.C. and the middle of the century. II a.C.

The most important scientific site of Phoenician occupation in the Mondego is Santa Olaia, discovered by Santos Rocha in the 19th century [75]. This place has been occupied since the Paleolithic until the Bronze Age [76], but its archaeological apogee manifests itself during the Iron Age. 
The Phoenician occupation at the Mondego is located between Santa Olaia and Maiorca, with its own foundry. It points to a raw metal collection station, from the expeditions north of the Iberian Peninsula, and transformed into ingots. During the Phoenician occupation, VII to IV BC [77], Santa Olaia was an island in the middle of the Mondego estuary [78], a large navigable port that allows the construction of ports for large draft vessels.

From the first explorations of Santos Rocha was the extraordinary ruins of a village with houses of orthogonal plan organized in streets with innumerable finds kept in the Municipal Museum Santos Rocha. More recently, at the time of construction of Freeway 17 an industrial Phoenician zone of metallurgical foundry was erected, and everything indicates that there were ports to load the Phoenician ships with ingots of the molten material [78].

In addition to Santa Olaia, the Ferrestelo hill is considered the possible necropolis of this Phoenician village, corroborated by the existence of a water line separating the village from the necropolis (sionic theology). In addition to Santa Olaia, there was also a long-term occupation in the Castro de Tavarede [79] and in the Paião, the Castrodo Bizzoreiro of Castile, a plateau bordering the Pranto onte river there was a watchtower [61].

The Roman Occupation (150 BC to 476 AD) of the Council of Figueira da Foz is present in several points of the municipality, besides the occupation of the old Phoenician sites, like Santa Olaia [80], although without a definition of the typology [81] and Ferrestelo [79]. The discovery of the vicus portuarius in Maiorca, with a Roman road that leaves from this city to Quiaios [81], during which there were agricultural houses. Roman finds were found along the ridge line of the Serra de Brenha and Boa Viagem, with emphasis on tile kilns. To the south of the county there are also evidence of Roman existence with greater definition in Castro Bizzorreiro de Castela [61].

In the urban fabric, in addition to the Roman coins found, Roman building materials were recently found in the Fort of Santa Catarina, which would correspond to a building of a signpost or watchtower at the entrance of the Mondego [82]. The same thesis may be applied to the ruin of a Fortim on the Cape Mondego, recently discovered [83], however, without an excavation in the place it will not be possible to give this fact for sure.

\subsection{Medieval and Modern Age-The Base of Now Days Settlements}

The first village that formed in the county, still today part of the toponymy, were formed generally before the formation of the kingdom during the Middle Ages (between the 5th and 15th centuries), with Tavarede and Buarcos still preserving an urban layout with medieval features. However, the most promising elements are the military defense buildings, the Buarcos Fortress, begun in the 14th century, while the Fort of Santa Catarina and the Battery of Palheiros, were built in the Modern period.

Of the several existing buildings stands out the Quinta de Foja, an agricultural holding unit of rice, with an excellent state of conservation, maintaining the architectural draw from the Crúzio domain [84].

Of the most recent works, and relevant in the geomorphological context, was the Vale do Sampaio Aqueduct, a project of the end of the 19th century, of Eng. Nery Delgado, where a chapel was built with the function of storing water resources, in the 11th century [81]. This aqueduct has a gallery with more than $1 \mathrm{~km}$ and $2 \mathrm{~m}$ high, still existing today [85].

When it comes to industrial heritage, Cape Mondego appears as a high-profile coal mining operation in the country [86-88]. We find in the landscape the most distinct marks of time, from dinosaur tracks, to prehistoric civilizations, to the discovery of coal, to the reminiscences of the Industrial Revolution, and to mining exploration craters that have changed the morphology of the place. The industrial complex develops along the coast road that connects the Marginal da Figueira da Foz to the Murtinheira road. The coal mines, which begun in 1750 and were closed in 1967, are more than $3 \mathrm{~km}$ long [89]. The industrial structure includes a built structure which, in addition to coal mining, has been used for the production of whitewash, cement, glass, briquettes and electricity. The study of this place allows a reliable contextualization of the evolution of human techniques from 
the industrial revolution to the present day, taking as its motto the use of natural resources [83]. In addition to the industrial heritage value is added the geological and paleontological interest certified by the classification of the Cabo Mondego Natural Monument and the Global Stratotype Section and Point of Bajociano.

\section{Geotourism and Public Engagement}

The economic significance of tourism and the potential of tourism should not be underestimated, and the great chance for the further development should be perceived in the rapidly increasing form of geotourism. Geotourism is a new niche market of tourism centred on sustaining and enhancing the geological character of a place [90].

It is evident that the European Geoparks Network and the Global Geoparks Network have introduced geotourism as a target for geopark creation, and they introduced the network concept to geotourism activities. Results of researches indicate that developing geotourism in geoparks stimulates local socio-economic activities through attracting increasing numbers of visitors. It encourages production of local products and local handicrafts involved in geotourism and geo-marketing [91,92].

The geotourism experience pretends to create a holistic experience, enhancing primarily the geology and landscapes interpretation, but also geographical character, culture, environment, heritage, and the well-being of its residents.

As a fundamental part of the natural world, geology and landscape have had a profound influence on society, civilization, and cultural diversity, especially in regard to the formation and location of mineral and energy resources, without which modern societies could not function.

The communication of geoscientific issues and "geo-knowledge" is not trivial [93]. Geoscientific topics must be presented in an interesting manner and use the associated landscape experience in order to enhance its value.

Various groups have different level of interest and require different levels of geological knowledge. To facilitate the public engagement and knowledge transfer in the Aspiring Jurassic Geopark of Figueira da Foz, specific instruments were used simultaneously (Figure 5), including:
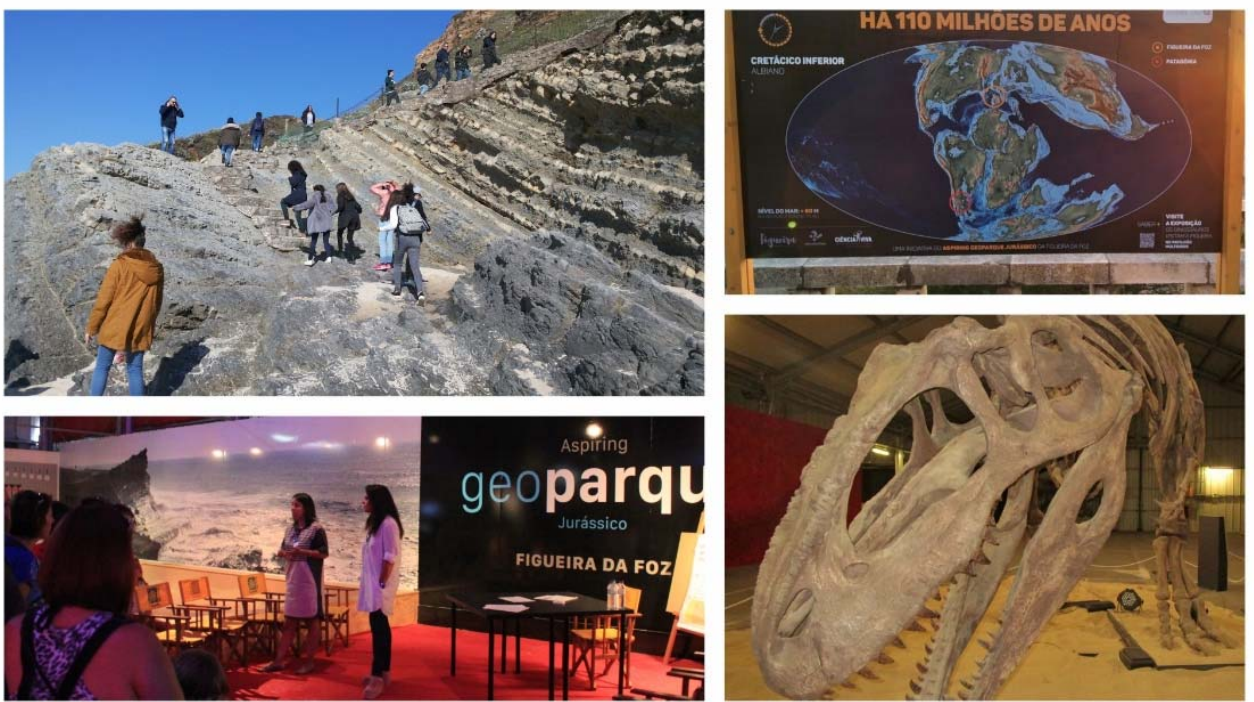

Figure 5. Images of some of the activities conducted by "Aspiring Jurassic Geopark of Figueira da Foz". By Aspiring Jurassic Geopark of Figueira da Foz.

\subsection{Exhibitions}

The oldest known scientific reference to dinosaur tracks in Portugal goes back to Gomes (1915-1916) that in 1884 discovered an Upper Jurassic bed containing dinosaur foot-prints at Pedra 
da Nau beach, Cape Mondego, Figueira da Foz. This early report is one of the first references to the excavation and the study of dinosaur tracks in the world [94].

Taking this into account the exhibition "Os Dinossauros visitam a Figueira" (The Dinossaurs Visit Figueira) was held between 22 July 2017 and 31 March 2018. The exhibition had a total of 21,000 visitants.

\subsection{Interpretative Panels}

Environmental interpretation is part of environmental education, being the term used to describe communication activities undertaken to better understand the natural environment [95], and there are several techniques that can be used such as interpretative panels.

In Figueira da Foz 13 clear design (with variation of font size, block diagrams and pictures to aid comprehension) interpretative panels, named "walking through time", have been displayed alongside the main beach avenue explaining the continental drift, following a progressive idea in relation to geologic time. Since they are always available and in two languages (Portuguese and English) they serve a large number of visitors.

\subsection{Guided Tours}

In psychological terms, in some groups, guided tours help to achieve learning and, by helping visitors to better understand the surrounding environment, their awareness may be enhanced [96].

Thematic guided tours have been happening. During these tours visitants may have the chance to visit geomonuments, landscapes, important bird areas, museums, anthropomorphic and industrial heritage, and other areas with relevance for the Aspiring Geopark.

\subsection{Talks}

Talks and discussion groups are a good way to give opportunities to share and debate ideas informally, providing opportunities to clarify ideas and expose participants to new concepts and perspectives [97].

Every Saturday afternoon, between August and September 2017, the Aspiring Jurassic Geopark team got together for interactive thematic talks, with around 80 participants each, from several backgrounds, ages and interests.

\subsection{Media Coverage}

Media and communication have never held greater global relevance or significance. Press coverage is important to diffuse information and build support, promote understanding, and encourage more informed decision-making at all levels, from stakeholders to communities to individuals [98].

Even though the Aspiring Jurassic Geopark of Figueira da Foz had national press coverage (TV and newspaper), one of the concerns of the team during 2017 was to promote the Aspiring Geopark at the regional and local newspapers, in order to promote local public awareness and engagement and make the Aspiring Jurassic Geopark of Figueira da Foz more diverse and inclusive.

\subsection{Other Campaigns}

Other campaigns included advertisement in outdoors, cultural agenda and cars (after a sponsorship from a national company), workshops for children, talks and guided tours with students and teachers, book publication, and partnerships with local outdoor activities associations and companies (trekking, sailing).

With the purpose of understanding if the first communication strategies used were succeeding, a small query was conducted and demonstrated that $81 \%$ of Figueira da Foz population recognizes the importance of their geoheritage and $67 \%$ already knows that an application for UNESCO is being prepared. 


\section{Conclusions}

The use of geodiversity, biology and antropic heritage to foster economic sustainable development through the promotion of education and tourism in Figueira da Foz came at first place as a municipal interest and has its public recognition by the local community and by the press (national and local). The methods used to create public awareness and participation in geoparks' application demonstrated to be an amplifying factor of this recognition.

This area is a catalogue of scientific, touristic and educational values that is being used for a long time, and all of the work that is being done recently got the recognition by UNESCO. In 2018 Figueira da Foz became officially an Aspiring Geopark and was given the chance to create the first Geopark in the Lusitanian Basin. This Aspiring Geopark aims to be a role model of development based on the conservation and valorisation of its heritage, with the community's involvement.

Author Contributions: $\quad$ Supervision, P.T.; Conceptualization, P.T. and E.L.; Coordination P.T. and E.L.; Methodology, P.T. and E.L; Public Public Engagement, P.T. and E.L.; Geology, Software and Photography, J.d.C.; Patrimony, S.A.; Tourism and Culture, M.P.

Conflicts of Interest: The authors declare no conflict of interest.

\section{References}

1. Ministério do Ambiente. Do O. do T. e do D. R. Decreto Regulamentar no 82/2007, de 3 de Outubro. 2007, pp. 7091-7092. Available online: https:/ / dre.pt/application/conteudo/641729 (accessed on 1 April 2018).

2. Pena dos Reis, R.; Henriques, M.H. Geoheritage and advanced training for the oil industry: The Lusitanian Basin case-study (Portugal). Am. Assoc. Pet. Geol. Bull. 2017. [CrossRef]

3. Choffat, P. Étude stratigraphique et paléontologique des terrains jurassiques du Portugal. Le Lias et le Dogger au Nord du Tage. Mem. Sec. Trab. Geol. Port. 1880, XXII, 72.

4. Ruget-Perrot, C. Études stratigraphiques sur le Dogger et le Malm Inférieur du Portugal au Nord du Tage. Bajocien, Bathonien, Callovien, Lusitanien. Mem. Serv. Geol. Port. 1961, 7, 197.

5. Barbosa, B. (Coord) Carta Geológica de Portugal, Na Escala de 1:50.000: Folha 19-A (Cantanhede), 2nd ed.; LNEG: Lisbon, Portugal, 2008.

6. Manuppella, G.; Rocha, R.B.; Soares, A.F. Carta Geológica de Portugal, Na Escala de 1:50.000: Folha 19-C (Figueira da Foz); LNEG: Lisbon, Portugal, 1976.

7. Duarte, L.V.; Soares, A.F. Litoestratigrafia das séries margo-calcárias do Jurássico inferior da Bacia Lusitânica (Portugal). Comun. Inst. Geol. Min. 2002, 89, 135-154.

8. Soares, A.F.; Duarte, L.V. Tectonics and eustatic signatures in the Lower and Middle Jurassic of the Lusitanian Basin. In Proceedings of the Comunicaciones IV Congreso Jurásico de España; Institucion Fernando el Catolico: Zaragoza, Spain, 1997; pp. 111-114.

9. Azerêdo, A.C.; Duarte, L.V.; Henriques, M.H.; Manuppella, G. Da Dinâmica Continental no Triásico, Aos Mares do Jurássico Inferior e Médio. Cadernos de Geologia de Portugal; Instituto Geológico Mineiro: Lisbon, Portugal, 2003; p. 43. ISBN 972-98469-9-5.

10. Duarte, L.V. Facies analysis and sequential evolution of the Toarcian-Lower Aalenian series in the Lusitanian Basin (Portugal). Comun. Inst. Geol. Min. 1997, 83, 65-94.

11. Pena dos Reis, R.; Pimentel, N.L.; Garcia, A. A Bacia Lusitânica (Portugal): Análise estratigráfica e evolução geodinâmica. Bol. Geocienc. Petrobras 2010, 19, 23-52.

12. Barbosa, B.; Soares, A.F.; Rocha, R.B.; Manuppella, G.; Henriques, M.H. Carta Geológica de Portugal, na escala de 1:50,000: Noticia Explicativa da Folha 19-A (Cantanhede); Serviços Geológicos de Portugal: Lisboa, Portugal, 1988.

13. Henriques, M.H. Biostratigrafia e Paleontologia (Ammonoidea) do Aaleniano em Portugal (Sector Setentrional da Bacia Lusitaniana). Ph.D. Thesis, University of Coimbra, Coimbra, Portugal, Unpublished work. 1992.

14. Watkinson, M.P. Triassic to Middle Jurassic Sequences from the Lusitanian Basin Portugal, and their equivalents in other North Atlantic margin basins. Ph.D. Thesis, The Open University, Milton Keynes, UK, Unpublished work. 1989. 
15. Azerêdo, A.C. Jurássico médio do Maciço Calcário estremanho (Bacia Lusitânica): Análise de fácies, micropaleontologia, paleogeografia. Ph.D. Thesis, Universidade de Lisboa, Lisboa, Portugal, Unpublished work. 1993.

16. Henriques, M.H.; Linares, A.; Sandoval, J.; Ureta, M.S. The Aalenian in the Iberia (Betic, Lusitanian and Iberian Basins). Geo. Res. Forum. 1996, 1, 139-150.

17. Henriques, M.H.; Gardin, S.; Gomes, C.R.; Soares, A.F.; Rocha, R.B.; Marques, J.F.; Lapa, M.R.; Montenegro, J.D. The Aalenian-Bajocian boundary at Cabo Mondego (Portugal). Misc. Ser. Geol. Naz. 1994, 5, 63-67.

18. Pavia, G.; Enay, R. Definition of the Aalenian-Bajocian Stage Boundary. Episodes 1997, 20, 16-22.

19. Fernández-López, S.R.; Pavia, G.; Erba, E.; Guiomar, M.; Henriques, M.H.; Lanza, R.; Mangold, C.; Morton, N. The Global Boundary Stratotype Section and Point (GSSP) for base of the Bathonian Stage (Middle Jurassic), Ravin du Bès Section, SE France. Episodes 2009, 32, 222-248.

20. Fernández-López, S.R.; Henriques, M.H.; Mangold, C. Ammonite succession at the Bajocian/Bathonian boundary in the Cabo Mondego region (Portugal). Lethaia 2006, 39, 253-264. [CrossRef]

21. Canales Fernández, M.L.; García-Baquero, G.; Henriques, M.H.; Figueiredo, V.L. Palaeoecological distribution pattern of Early-Middle Jurassic benthic foraminifera in the Lusitanian Basin (Portugal) based on multivariate analysis. Palaeogeogr. Palaeoclimatol. Palaeoecol. 2014, 410, 14-26. [CrossRef]

22. Henriques, M.H.; Canales, M.L.; Silva, S.C.; Figueiredo, V. Integrated Biostratigraphy (Ammonoidea, Foraminiferida) of the Aalenian of the Lusitanian Basin (Portugal): A synthesis. Episodes 2016, 39, 482. [CrossRef]

23. Neto, K.A.; Henriques, M.H.; Antunes, R.L. Nanofósseis calcários da passagem Aaleniano-Bajociano do perfil do Cabo Mondego-Portugal (GSSP do Bajociano). Bol. Geocienc. Petrobras 2011, 19, 235-250.

24. Ferreira, J.; Mattioli, E.; van de Schootbrugge, B. Palaeoenvironmental vs. evolutionary control on size variation of coccoliths across the Lower-Middle Jurassic. Palaeogeogr. Palaeoclimatol. Palaeoecol. 2017, 465, 177-192. [CrossRef]

25. López-Otálvaro, G.-E.; Henriques, M.H. High-resolution calcareous nannofossil biostratigraphy from the Bathonian ASSP of the Cabo Mondego Section (Lusitanian Basin, Portugal). Newslett. Stratigr. 2018. [CrossRef]

26. Henriques, M.H.; Pena dos Reis, R.; Duarte, L.V. Locais com interesse geológico da orla costeira portuguesa entre o Cabo Mondego e a Nazaré. Comun. Inst. Geol. Min. 1998, 84, 6-9.

27. Henriques, M.H. Jurassic heritage of Portugal: State of the art and open problems. Riv. Ital. Paleont. Strat. 2004, 110, 389-392. [CrossRef]

28. Brilha, J.; Andrade, C.; Azerêdo, A.; Barriga, F.J.; Cachã, O.M.; Couto, H.; Cunha, P.P.; Crispim, J.A.; Dantas, P.; Duarte, L.V.; et al. Definition of the portuguese frameworks with international relevance as an input for the European geological heritage characterisation. Episodes 2005, 28, 177-186.

29. Pena dos Reis, R.; Henriques, M.H. Approaching an Integrated Qualification and Evaluation System for Geological Heritage. Geoheritage 2009, 1, 1-10. [CrossRef]

30. Rocha, J.; Brilha, J.; Henriques, M.H. Assessment of the geological heritage of Cape Mondego Natural Monument (Central Portugal). Proc. Geol. Assoc. 2014, 125, 107-113. [CrossRef]

31. Azerêdo, A.C.; Paul Wright, V.; Ramalho, J.M. The Middle-Late Jurassic forced regression and disconformity in central Portugal: Eustatic, tectonic and climatic effects on a carbonate ramp system. Sedimentology 2002, 49, 1339-1370. [CrossRef]

32. Rocha, R.B.; Marques, B.; Kullberg, J.C.; Caetano, P.; Lopes, C.; Soares, A.F.; Duarte, L.V.; Marques, J.; Gomes, C. The 1st and 2nd rifting phases of the Lusitanian Basin: Stratigraphy, sequence analysis and sedimentary evolution. In Final Report, CEC, Project MILUPOBAS. Unpublished work. 1986.

33. Teixeira, C. Flora Mesozóica Portuguesa. $1^{a}$ parte. Mem. Serv.Geol. Port. 1948, 2, 119.

34. Teixeira, C. Otozamites du Lusitanien du Cap Mondego, au Portugal. Bol. Soc. Geol. Port. 1972, 18, $121-122$.

35. Pais, J. Upper Jurassic plants from Cabo Mondego (Portugal). Bol. Soc. Geol. Port. 1974, 19, $19-45$.

36. Gomes, J.P. Descoberta de restos de sáurios gigantescos no Jurássico do Cabo Mondego. Com. Serv. Geol. Port. 1915, 11, 132-134.

37. Lapparent, A.F.; Zbyszewski, G. Les dinosauriens du Portugal. Mem. Serv. Geol. Port. 1957, 2, 1-63.

38. Vianna, A. Um peixe do Lusitaniano do Cabo Mondego. Com. Serv. Geol. Port. 1949, 30, 13-21.

39. Gonçalves, F. Lepidotus do Jurássico do Cabo Mondego. Bol. Mus. Lab. Min. Geol. Fac. Ciênc. Univ. Lisboa 1959, 8, 3-5.

40. Wright, V.P. Algal marsh deposits from the Upper Jurassic of Portugal. In Palaeoalgology: Contemporary Research and Applications; Toomey, D.F., Nitecki, M.H., Eds.; Springer: New York, NY, USA, 1985; pp. 330-341. 
41. Wilson, R.C. A reconnaissance study of Upper Jurassic sediments of the Lusitanian Basin. Ciênc. Terra Univ. Nov. Lisboa 1979, 5, 53-85.

42. Ribeiro, A.; Antunes, M.T.; Ferreira, M.P.; Rocha, R.B.; Soares, A.F.; Zbyszewski, G.; Moitinho de Almeida, F.; Carvalho, D.; Monteiro, J.H. Introduction à la Géologie Générale du Portugal; Serviços Geológicos de Portugal: Lisboa, Portugal, 1979; p. 114.

43. Dinis, J.L.; Rey, J.; Cunha, P.P.; Callapez, P.; Pena dos Reis, R. Stratigraphy and allogenic controls of the western Portugal Cretaceous: An updated synthesis. Cretac. Res. 2008, 29, 772-780. [CrossRef]

44. Trincão, P. Esporos e pólenes do Cretácico Inferior (Berriasiano-Aptiano) de Portugal: Paleontologia e Biostratigrafia. Ph.D. Thesis, Universidade Nova de Lisboa, Lisboa, Portugal, 1990.

45. Friis, E.M.; Pedersen, K.R.; Crane, P.R. Early Cretaceous mesofossils from Portugal and eastern North America related to the Bennettitales-Erdtmanithecales-Gnetales group. Am. J. Bot. 2009, 96, 252-283. [CrossRef] [PubMed]

46. Berthou, P.Y. Repartition stratigraphique actualisee des principaux foraminireres benthiques du Cretace moyen et superieur du Bassin Occidental Portugais. Benthos 1984, 83, 45-54.

47. Callapez, P. The Cenomanian-Turonian transition in West Central Portugal: Ammonites and biostratigraphy. Cienc. Terra U.N.L. 2003, 15, 53-70.

48. Callapez, P. Estratigrafia e Paleobiologia do Cenomaniano-Turoniano. 0 significado do eixo da Nazaré-Leiria-Pombal. Ph.D. Thesis, Coimbra University, Coimbra, Portugal, 1998.

49. Ramos, A.; Cunha, P.P.; Gomes, A. Os traços geomorfológicos da área envolvente da Figueira da Foz e a evolução da paisagem durante o Pliocénico e o Plistocénico. Pub. Ass. Port. Geomorfól. 2009, VI, 9-16.

50. Ramos, A.; Cunha, P.P. Facies associations and palaeogeography of the zancleanpiacenzian marine incursion in the Mondego Cape-Nazaré area (onshore of Central Portugal). In Proceedings of the 23rd International Meeting of IAS, Coimbra, Portugal, 15-17 September 2004; Pena dos Reis, R., Callapez, P., Dinis, P., Eds.; p. 227.

51. Soares, A.F. As unidades Pliocénicas e Quaternárias no espaço do Baixo Mondego (uma perspectiva de ordem). Estud. Quat. 1999, 2, 7-17.

52. Almeida, A.C. A carsificação da Serra da Boa Viagem, um processo quaternário. Estudos do Quaternário 2001, 4, 211-233.

53. Almeida, A.C. Dunas de Quiaios, Gândara e Serra da Boa Viagem. Uma abordagem ecológica da paisagem, Ph.D. Thesis, Faculdade de Letras Universidade de Coimbra, Coimbra, Portugal, 1995.

54. Ramos, A.M. Organização e significado dos depósitos mais recentes do estuário do rio Mondego. Master's Thesis, University of Coimbra, Coimbra, Portugal, 2000.

55. Barbosa, B.; Soares, A.F.; Rocha, R.B.; Manuppella, G.; Henriques, M.H. Nota Explicativa da Folha 19-A (Cantanhede); Laboratório Nacional de Energia e Geologia: Lisbon, Portugal, 2008.

56. Cunha, P.P.; Dinis, J.L. Sedimentary dynamics of the Mondego estuary. In Aquatic Ecology of the Mondego River Basin. Global Importance of Local Experience; Pardal, M.A., Marques, J.C., Graça, M.A., Eds.; Imprensa da Universidade: Coimbra, Portugal, 2002; pp. 43-62.

57. Soares, A.F. O Baixo Mondego: Realidade E Mito; Academia das Ciências de Lisboa: Lisbon, Portugal, 2017.

58. Fernández Salas, L.M.; Durán, R.; Mendes, I.; Galparsoro, I.; Lobo, F.J.; Bárcenas, P.; Rosa, F.; Ribó, M.; García-Gil, S.; Ferrín, A.; et al. Shelves of the Iberian Peninsula and the Balearic Islands (I): Morphology and sediment types. Bol. Geol. Min. 2015, 2, 377-408.

59. Dias, J.M. Dinâmica sedimentar e evolução recente da plataforma continental portuguesa setentrional. Ph.D. Thesis, University of Lisbon, Lisbon, Portugal, 1987.

60. Oliveira, J.T.; Pereira, E.; Ramalho, M.; Antunes, M.T.; Monteiro, J.H. Carta Geológica de Portugal, na escala de 1:500,000: Folha Norte, 5th ed.; LNEG: Lisbon, Portugal, 1992.

61. Ferreira, A.M. Carta Arqueológica co Concelho da Figueira da Foz; Câmara Municipal: Figueira da Foz, Portugal, 2017.

62. Rocha, A.S. O Museu Municipal da Figueira da Foz: Catálogo Geral; Wentworth Press: Figueira da Foz, Portugal, 1905.

63. Callapez, P.M.; de Carvalho, M. As "Areias de Várzea do Lírio" e o Neolítico da Serra da Boa Viagem (Figueira da Foz, Portugal): Influência da envolvente geológica do meio natural na neolitização do território. Estud. Quat. Quat. Stud. 2010, 6, 37-47. 
64. Callapez, P.M.; de Carvalho, M. Contributos da envolvente geológica para o povoamento da Serra da Boa Viagem durante a Pré-história recente. In Santos Rocha a Arqueologia. 2012. Available online: https:/ / www.researchgate.net/profile/Pedro_Callapez/publication/259784973_Contributos_da_ envolvente_geologica_para_o_povoamento_da_Serra_da_Boa_Viagem_durante_a_Pre-Historia_Recente/ links / 02e7e52de4802e769a000000/Contributos-da-envolvente-geologica-para-o-povoamento-da-Serrada-Boa-Viagem-durante-a-Pre-Historia-Recente.pdf (accessed on 1 April 2018).

65. Rocha, A.S. Vestígios romanos no vale do Mondego e imediações. In O Arqueólogo Português, 2nd ed.1896; pp. 154-158. Available online: http:/ / www.patrimoniocultural.gov.pt/static/data/publicacoes/o_ arqueologo_portugues/serie_1/volume_2/154_vestigios_romanos.pdf (accessed on 1 April 2018).

66. Rocha, A.S. A profanação das antas na ephoca romana; Revista de Sciencias Naturaes e Sociaes: Porto, Portugal, 1895; pp. 5-9.

67. Pereira, I. Crasto. In Idade do Ferro: Catálogo; Serviços culturais, Figueira da Foz: Figueira da Foz, Portugal, 1994; pp. 28-38.

68. Vvilaça, R. Subsídios Para o Estudo da Pré-História Recente do Baixo-Mondego; IIP: Lisboa, Portugal, 1988.

69. Rocha, A.S. Estação luso-romana da Pedrulha. Boletim da Sociedade Archeologica Santos Rocha 1904, 1, 15-16.

70. Cruz, P.B. Materiais para o estudo do Neolítico no concelho da Figueira: Utensílios e armas. Boletim da Sociedade Archeologica Santos Rocha 1904, 2, 51-55.

71. Cruz, P.B. Materiais para o estudo do Neolítico no concelho da Figueira: Estação humana do Arneiro. BSASR 1904, 1, 10-12.

72. Rocha, A.S. Estação neolítica do Forno da Cal na Vinha da Rainha. In Memórias Sobre a Antiguidade; Imprensa Lusitana: Figueira da Foz, Portugal, 1897; pp. 91-102.

73. Coffyn, A. Le Bronze Final Atlantique Dans la Péninsule Ibérique; Difusion de Boccard: Paris, France, 1985.

74. Kalb, P. Monumentos megalíticos entre Tejo e Douro. In Megalitismo en la Peninsula Ibérica; Ministério da Cultura: Madrid, Espana, 1987; pp. 95-109.

75. Rocha, A.S. Cemitério do século XV em Lírio. Boletim da Sociedade Archeologica Santos Rocha 1907, 8, $226-227$.

76. Pereira, I. Santos Rocha e o estudo da Idade do Ferro em Portugal. In Santos Rocha a Arqueologia e a Sociedade do Seu Tempo; Coord. de Raquel Vilaça e Sónia Pinto; Casino Figueira: Figueira da Foz, Portugal, 2012.

77. Arruda, A.M. Fenícios (em Portugal). In Dicionário da Arqueologia Portuguesa; Figueirinhas: Porches, Portugal, 2012; pp. 158-159.

78. Wachsmann, S. Paleo-environmental contexts of phoenician anchorages, Portugal. Naut. Archaeol. 2009, 38, 221-253. [CrossRef]

79. Pereira, I. Casais agrícolas da Idade do Ferro na Foz do Mondego-Figueira da Foz. Conimbriga 1994, 32-33, 77-85.

80. Rocha, A.S. Restos de dólmens em Santa Olaia. Boletim da Sociedade Archeologica Santos Rocha 1907, 4, 123.

81. Alarcão, J. Territorio Colimbrie: Lugares Velhos (e Alguns Deles Deslembrados) do Mondego, IPA; Trabalhos de arqueologia: Lisboa, Portugal, 2004.

82. Roquinho, P.; Reconstrução, Reabilitação e Espaços Interiores do Forte de Santa Catarina Figueira da Foz-2015. Sondagem e acompanhamento arqueológico, Figueira da Foz, Portugal. Personal communication, 2016.

83. Goulão, J.S.A. O caso do Cabo Mondego. O dever da Arquitetura sobre o território abandonado. Master's Thesis, Universidade de Coimbra, Coimbra, Portugal, 2016.

84. Bobone, C. A Quinta de Foja do Século XI ao Século XXI; Lisboa Edições INAPA: Lisboa, Portugal, 2005.

85. Brandão, J.M.; de Callapez, P.M. Um projeto oitocentista de captação de águas subterrâneas: $\mathrm{O}$ abastecimento à cidade da Figueira da Foz (Portugal). In XIII Congreso Internacional Sobre Patrimonio Geológico y Minero; Manresa: Catalunya, España, 2012; pp. 20-23. Available online: http:/ / repositorio.lneg.pt/bitstream/10400. 9/1837/1/35568.pdf (accessed on 1 April 2018).

86. Callapez, P.M. Subsídios para um roteiro geoturístico do litoral português: O exemplo da Figueira da Foz. In Por Terras da Figueira da Foz; Lopes, F.C., Callapez, P.M., Eds.; Kiwanis Clube da Figueira da Foz: Figueira da Foz, Portugal, 2008; pp. 115-129.

87. Callapez, P.M.; Pinto, J.S. Tesouros geológicos e naturais da Região da Figueira da Foz: Perspectivas de intervenção no Ensino Básico e Secundário. Litor. Rev. Estud. Fig. 2005, 3, 57-81.

88. Callapez, P.M.; Pinto, J.S. Uma laguna tropical no Jurássico Superior do Cabo Mondego. Litor. Rev. Estud. Fig. 2010, 11, 95-116. 
89. Pinto, J.S.; Callapez, P.M. O património mineiro do Cabo Mondego. Litor. Rev. Estud. Fig. 2006, 4, 67-80.

90. Hose, T.A.; Marković, S.B.; Komac, B.; Zorn, M. Geotourism-A short introduction. Acta Geogr. Slov. 2011, 51, 339-342. [CrossRef]

91. Farsani, T.N.; Coelho, C.; Costa, C. Geotourism and geoparks as novel strategies for socio-economic development in rural areas. Int. J. Tour. Res. 2011, 13, 68-81. [CrossRef]

92. Zouros, N. Lesvos Petrified Forest Geopark, Greece: Geoconservation, Geotourism, and Local development. George Wright Forum J. 2010, 27, 19-28.

93. Frey, M.L.; Schäefer, K.; Büchel, G.; Patzak, M. Geoparks-A regional, European and global policy. In Geotourism; Dowling, R., Newsome, D., Eds.; Elsevier, Ltd.: Oxford, UK, 2006; ISBN 0-7506-6215-8.

94. Callapez, P.M.; Pinto, J.S.; Brandão, J.M.; Santos, V.F.; Azenha, M.; Pinto, R. A mina de carvão do Cabo Mondego e a Paleontologia Portuguesa. In Memórias do Carvão; Brandão, J.M., Nunes, M.F., Eds.; Câmara Municipal da Batalha e Câmara Municipal de Porto de Mós: Batalha e Porto de Mós, Portugal, 2015; pp. 235-258. ISBN 978-989-8210-23-4.

95. Vasconcelos, J. Interpretação ambiental. In Manual de Ecoturismo de Base Comunitária; WWF Brasil: Brasília, Brazil, 2003; pp. 261-294. ISBN 85-86440-12-4.

96. Tisdell, C.; Wilson, C. Wildlife-based tourism and increased support for nature conservation financially and otherwise: Evidence from sea turtle ecotourism at Mon Repos. Tour. Econ. 2001, 7, 233-249. [CrossRef]

97. Feliú-Mójer, Effective Communication, Better Science, Scientific American. 2015. Available online: https: / /blogs.scientificamerican.com/guest-blog/effective-communication-better-science/ (accessed on 1 April 2018).

98. Dietram, A.S. Science communication as political communication. Proc. Natl. Acad. Sci. USA 2014, 111 (Suppl. 4), 13585-13592. [CrossRef]

(C) 2018 by the authors. Licensee MDPI, Basel, Switzerland. This article is an open access article distributed under the terms and conditions of the Creative Commons Attribution (CC BY) license (http:/ / creativecommons.org/licenses/by/4.0/). 